\title{
Tigers and Leopards in Russia's Far East
}

\author{
David Prynn
}

\begin{abstract}
Russian settlement of the Far East inevitably reduced numbers of Siberian tigers and leopards, whose magnificent skins were a major lure for the settlers. But in the 1880 s tigers were numerous, and tracks often seen in the streets of Vladivostok; many were shot. Today there may be 200 or so, which is probably as many as at any time since 1914. Now fully protected, they appear to have adjusted to the timber mills and the secondary forest, and are often seen on roads and near gardens. Their main strongholds are two rèserves, both likely to be enlarged. The leopard, however, is seriously endangered, and depends for survival on two reserves in the Ussuri region which are being combined to create one huge reserve 200 miles long.
\end{abstract}

Just as in the 17 th century the quest for the beautiful fur of the sable was a major factor in the spread of Russian settlement across Siberia, and in the 18th century the value of sea otter skins was partly responsible for Russian penetration across the Bering Sea into Alaska, so the exploitation of wildlife resources played some part in the settlement of the Amur-Ussuri river region and the Pacific seaboard of the Far East.

Winters in the region are long and severe with deep snow, but dry, clear and sunny; in the hot humid summers, under the influence of the monsoons, the air is as saturated with moisture as in the tropics, and plant life, dormant for months, bursts into frenzied growth. These areas include some of the most beautiful mixed forests in the world, with a great variety of trees and shrubs, and an impressive fauna.

The mammals include many North European species, among them European elk Alces alces, lynx Felis lynx, wolf Canis lupus, and brown bear Ursus arctos; Indian fauna representatives include Himalayan black bear Selenarctos thibetanus, leopard cat Felis bengalensis, dhole (wild dog) Cuon alpinus, and yellow-throated marten Martes flavigula; many of Britain's mammal and bird species also occur in the Amur-Ussuri region.

The 17th century Russian pioneers, such as Khabarov, came into conflict with the aboriginal Tungus tribes of the area as well as with the Chinese, who were already tenuously established in these vast territories. There were many clashes between the Manchu troops and the Russian settlers supported by Cossack detachments, until the Treaty of Nerchinsk in 1689 left large areas north of the Argun-Amur rivers within the Chinese Empire. By the 1850s, however, Russian settlement had spread once more along the Amur, and in 1858 the Treaty of Aigun forced China (which also had to contend with British and French intervention at this time) to give up the territory north of the Amur to Russia. In 1860, by the Treaty of Peking, China ceded the land east of the Ussuri River, and that year the Russians founded the port of Vladivostok (meaning Rule the East) as a strong naval base on the Pacific.

Despite this political transfer, which was to be permanent, there were many Chinese settlers in the Ussuri territory until the early years of this century, even though the Tsarist government encouraged Russian settlement and the Manchu rulers of China discouraged Chinese migration into the north-east of 


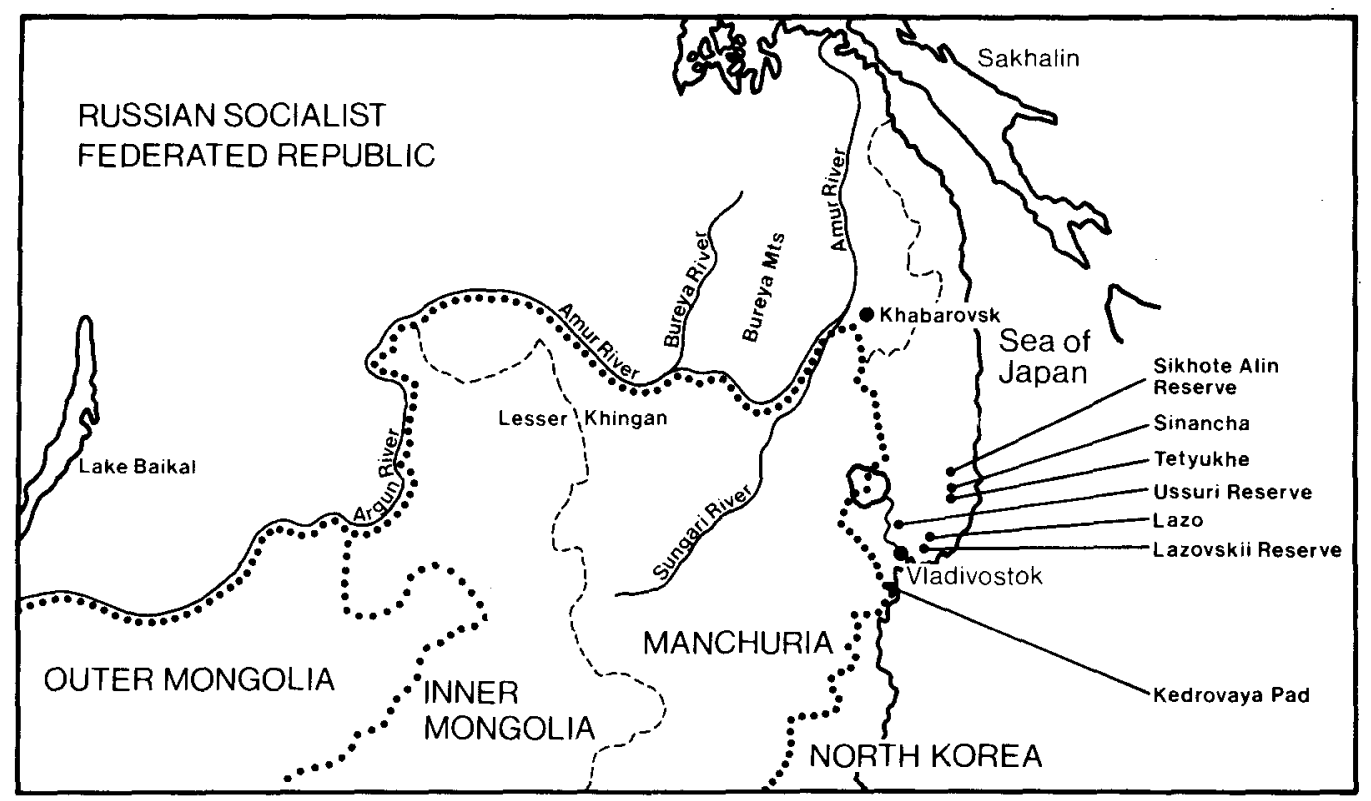

their own empire. Since 1900 the Chinese population of the Ussuri territory has given way to Russian settlers. ${ }^{2}$

The first Chinese to come into the Ussuri region, then sparsely inhabited by hunting and fishing tribes such as the Nanai and Udegei, were searching for ginseng for its medicinal value and hunting leopards and also sika deer for antlers 'in velvet'. Leopards were much sought after for their luxuriant and beautifully marked coats, which fetched high prices in the fur markets. The Chinese also used leopard bones and other parts but leopards were not as important as tigers in traditional medicine. Nor were they represented as frequently in Chinese art, perhaps because they did not figure so prominently in mythology. ${ }^{3}$

The Amur leopard Panthera pardus orientalis, also called the Korean, Far Eastern, East Siberian and North China leopard, is the most northerly leopard subspecies and one of the most beautiful of the world's cats, with a remarkably long, soft winter coat and a very long, furry tail. The background colour of the coat is a handsome pale straw yellow, or tan-beige, in Korea almost light grey; the underside is pure white, and the spot pattern usually of large, solid black rosettes. Adult males may weigh about 76 kilos. ${ }^{4}$ Its habitat, part of which it shares with the much larger Siberian tiger Panthera tigris altaica, consists of the mixed deciduous forests, where it prefers the most inaccessible, rocky parts of the mountains with numerous cliffs and fallen timber, and preys on young wild boar, goral, roe, musk, sika and red deer as well as smaller mammals such as the Manchurian hare and birds. Although the great explorer-naturalists Radde and Middendorff in the 1860 s reported the leopard from as far north as the Bureya Mountains on the left bank of the Amur, and Maak (1861) and Przewalski (1870) wrote that it occurred throughout the Ussuri region, it was invariably described as rarer than the magnificent Siberian tiger.

This tiger is the largest and most massively built subspecies, a tremendously powerful animal with a heavy bone structure, light yellow-ochre background colouring, distinct black stripes, large areas of white on the underside, and a mane-like ruff, especially in adult males. In winter it grows a long, thick, silky 
coat, and develops a layer of fat as insulation. ${ }^{5}$

In the 1880 s the Siberian, or more correctly Amur, tiger was very common in the Russian Far East, and it was not unusual to find fresh tracks in the snow on winter mornings in the outlying streets of Vladivostok. ${ }^{6}$ In some places settlers found it almost impossible to rear horses and other domestic stock because of the great cats' depredations, and the residents of Vladivostok even put up barriers around their houses, as there were man-eating tigers. Large numbers of tigers were shot or poisoned, as many as 150 a year in the $1880 \mathrm{~s}$ and $1890 \mathrm{~s}$, and 50-60 a year in 1900-1905. ${ }^{7}$

In the late 1890 s the completion of the Trans-Siberian Railway opened up the Russian Pacific seaboard to settlement, and widespread deforestation followed with uncontrolled felling and burning as land was cleared for agriculture, especially in the Khanka lowlands. Chinese crops such as millet, rice and soya beans were supplemented by melons and suger beet brought in by Ukrainian settlers. In the years before the First World War, as cultivation spread along the main river valleys the range of the tiger was reduced. Hunting greatly reduced the numbers of prey species such as wild boar, goral and red and sika deer; large numbers of tigers were shot for pelts and for products used in Chinese medicine, and an increasing number were captured for zoos. Hagenbeck of Hamburg offered up to $£ 1000$ each for live tigers at this time. ${ }^{8}$

Russian hunters preferred to track the animal down in the snow during the winter. Loukashkin described how the hunters worked in teams of four; two would follow the trail while the others transported the equipment and pitched camp. Once fresh tracks were found the tiger would be pursued, often for a week or more, before it was brought to bay.

Tigers were also profoundly affected by natural disasters. In the $1880 \mathrm{~s}$, according to Arseniev, tigers migrated from the Sungari River region of Manchuria eastwards into the Sikhote Alin mountains because widespread disease had reduced their prey species. Similarly, in the terrible winter of 1914, there were massive deaths among hoofed animals, and by the 1920s, Bannikov says, tigers survived only in isolated localities. Nevertheless, in the 1930s, despite their rarity, they could still be hunted throughout the year. In 1934 Sowerby reported that the number shot was actually increasing, for whereas usually about 10 were taken each year, 20 had already been killed in the first three months of that year. ${ }^{9}$

Although tigers were given some protection by the setting up of the great Sikhote Alin reserve in 1935 and the existence of large tracts of unspoiled forest, for example in the upper reaches of the Iman River, they were becoming scarcer. Industrial and agricultural development in the 1930s and the construction of power stations in the southern part of the Soviet Far East all resulted in the loss of habitat. After 1947 killing of tigers was generally prohibited (and the law tightened in 1956), but many young animals were still captured for export. From 1920 to 1960 almost as many tigers were caught for zoos as were killed by hunters. ${ }^{10}$ In the Soviet Far East alone more than 50 were captured by catching teams between 1939 and $1956,{ }^{11}$ and in the $1964 / 75$ winter no fewer than 15 were caught in the Iman River region alone. Sometimes the female would be shot while defending her young, and adults of both sexes were occasionally shot for study purposes. The largest Siberian tiger ever recorded was a male weighing 384 kilos shot in the Sikhote Alin mountains in 1950. 
Right: Pacific coast in the Sikhote Alin Nature Reserve.

Below: Aduit male Siberian tiger; an izurra, or Manchurian wapiti; three-month-old female Amur leopards; Ussuri wild boar, the tiger's main prey.

Photos: David Prynn (tiger); Panthera, J. of Liepzig Zoo (leopards); A.M. Kolosov 1978, The Fauna of the Far East and Its Protection in the BAM Zone, Moscow. . (n) (1) (1)
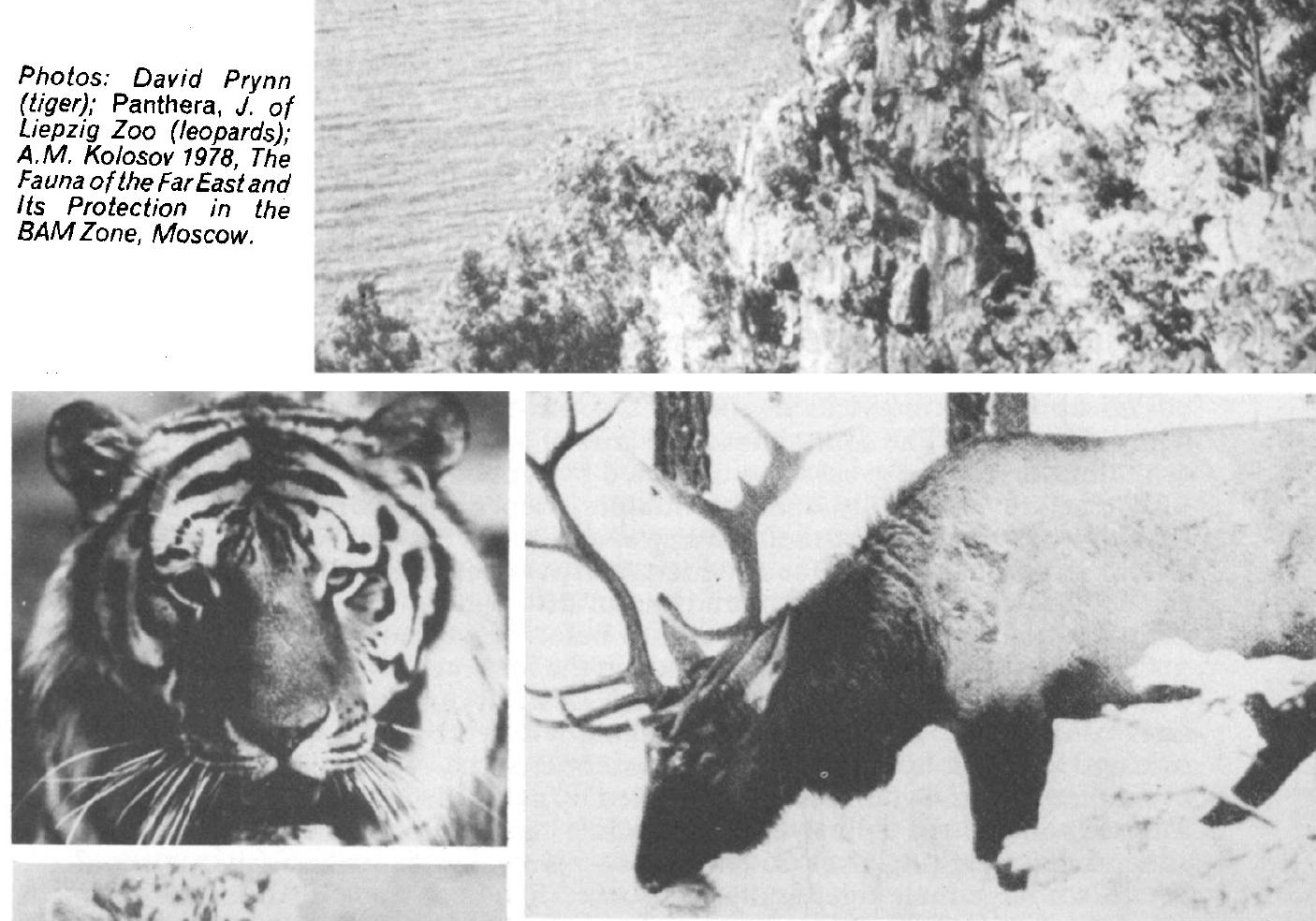

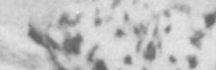
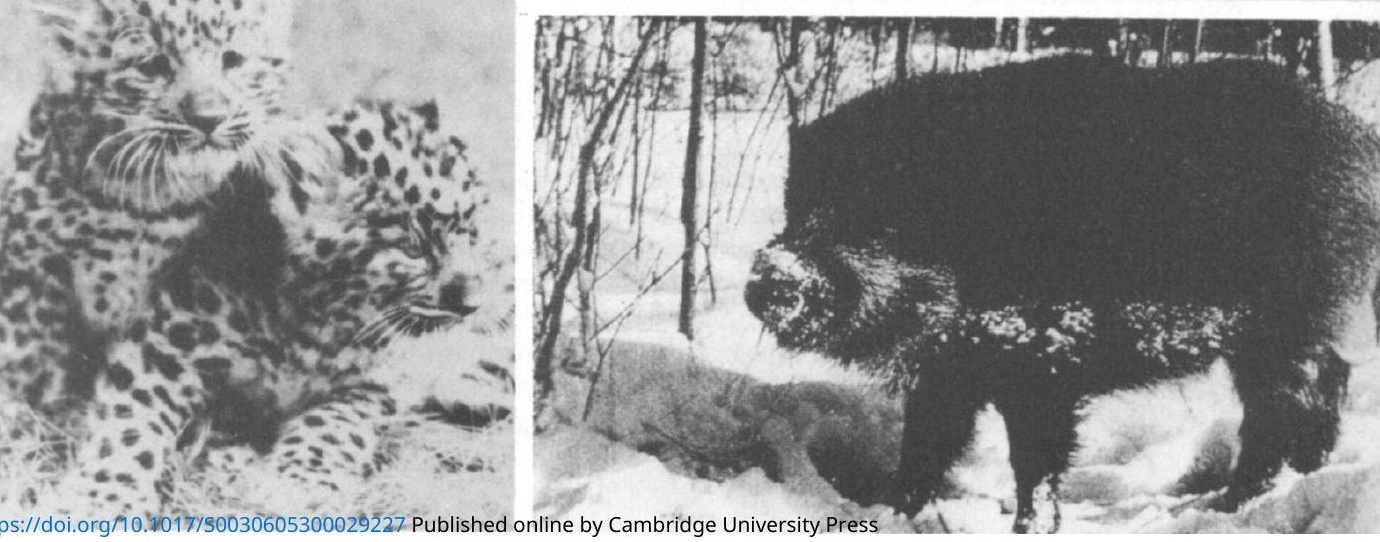
Today only one or two young tigers are captured each year under special licence, and, with the ban on shooting, numbers in the Soviet Far East rose from 20/30 in 1940, according to Kaplanov, to about 170 in 1976, according to Bromley in 1977. The number in the USSR today may be about 200. This may seem a very small number, but Siberian tigers have enormous territories ranging over hundreds of square kilometres and there may be as many now in the Soviet Far East as at any time since the First World War.

In the early 1940s the Amur tiger survived in only about five isolated areas in Primorye (Maritime Territory), but it has now recolonised many of the regions where it occurred in the early 20th century. The sparse tiger population in the Soviet Far East is of course largely the result of man's persecution and human disturbance, but the harsh conditions, in a land where severe winters with deep snow last $5 \frac{1}{2}$ months of the year, are also a factor.

Russian zoologists, including Kaplanov, Abramov, Yudakov, Pikunov and Matyushkin, have studied the habits of Amur tigers for many years from the evidence of tracks in the snow. Tigers travel great distances along river valleys and mountain ridges, seldom crossing watersheds. In conditions of heavy snow cover they find it easier to follow trails made by wild boar and other hoofed animals along the beds of frozen streams or even man-made paths. They quite frequently stop to rest at regular lying-up places sheltered from the wind, and although they tolerate low temperatures very well, they may rest for some time curled up in rock crevices in sheltered south-facing slopes, and bask in the winter sunshine. The sometimes have lairs of a more permanent type in caves or under the roots of great trees uprooted by typhoons. ${ }^{12}$

Tigers are essentially solitary hunters, depending particularly on their hearing; they may detect their quarry at a distance of over 500 metres. Then, after getting close enough for a sudden rush over perhaps 50 metres, they cover the ground with a series of bounds at an astonishing speed for such a huge animal, often catching their prey almost before it has moved.

Of a series of 690 tiger kills examined in the Sikhote Alin, 54 per cent were of wild boar and 37 per cent red deer. With an adult quarry of either species the tiger usually leaps on to its back, bringing it down by pulling its head to one side and killing it by biting the neck vertebrae at the base of the skull. In cases of smaller prey the victim is usually killed by a blow from the tiger's enormous forepaws along the spinal column. Adult male wild boars are formidable adversaries weighing over 250 kilos, and Bromley describes a battle royal between a large male tiger and an old boar. The boar was killed but the tiger was later found dead of its wounds about $45 \mathrm{~km}$ away. ${ }^{13}$ Tigers occasionally prey on roe, musk and sika deer, goral and elk, and even eat brown and black bears. In the 1940s Kaplanov recorded an incident in the Sikhote Alin Reserve when a tigress killed a she bear and two cubs. However, big brown bears have been known to kill and eat immature tigers. ${ }^{11}$

The Amur tiger depends for its survival on wild boar and red deer in sufficient numbers. In a bad year for Korean pine kernels and other food, the boar lose condition in the winter and do not breed. The tigers may then turn their attention to the deer, which prefer the secondary forest with dense undergrowth that is also favoured by the tiger. Where there is much human disturbance the tigers need a larger number of prey on which to survive and do not breed so freely, resulting in fewer cubs. ${ }^{14}$

In the 1860 s and 1870 s the Amur tiger occurred throughout the mixed 
deciduous Manchurian forests of the NE Asia mainland. They were known to wander from their stronghold in the Bureya-Little Khingan Mountain region on the left bank of the Amur as far west as Lake Baikal and other parts of the Transbaikal region, and in 1905 they were recorded far to the north near Yakutsk. They were common throughout the Ussuri territory, and, as the Rev. A. Williamson commented in 1870 , numerous throughout the great 'forest-sea' of north-east China and North Korea. ${ }^{15}$ No doubt in former times Amur tigers were found farther west in Mongolia, and the now extinct Lop Nor tiger from Sinkiang, with its light colour and long fur, seems to have been intermediate between the Amur and Turan (Caspian) subspecies. To the south the Amur tiger probably intergraded with the smaller Chinese tiger in the region north of the Hwang-ho.

\section{Effect of the Railway}

Although tiger numbers in the southern part of the USSR Maritime Territory may now be at a maximum, their overall distribution is much more restricted than formerly. They are now rarely found in the Bureya Mountains and only in very small numbers in the Khabarovsk Territory, and there have been proposals recently that some might be captured in the south of the region and released farther north. The building of the Baikal-Amur railway is opening up huge formerly undisturbed areas, although protected areas are being set up along the route. The large numbers of military personnel on both sides of the sensitive Sino-Soviet border can hardly be an advantage to the wildlife.

Tigers are now found in areas of growing human activity, as Matyushkin points out, with agriculture and timber exploitation developing around protected areas. Khabarovsk and Vladivostok are great industrial centres and Nakhodka is a major container terminal. Around the Sikhote Alin Reserve there is saw milling at Iman, canning at Terney, zinc and lead mining at Tetyukhe and tin mining at Lifudzin and Sinancha. The whole of the Soviet Far East is a major timber producing area and a main source of fur-bearing animals, providing about a third of the USSR's harvest of pelts.

To some extent tigers have adjusted to these activities. Secondary forest has favoured the red and roe deer rather than the wild boar, which prefers mature Korean pine and oak forest, so the tigers prey more on the former, and in recent years they have often been seen on roads used for hauling timber and hunting close to gardens. They avoid man but do not seem to fear him. But attacks on cattle caused by the decline in the numbers of hoofed animals have become a serious problem in recent years in some areas - 386 cases in 1966-70. Partly as a result tigers are increasingly killed by poachers - at least 70 between 1965 and 1977. Most of these were shot by hunters, who believe that tigers reduce the number of deer and wild boar, although poachers kill far more game than tigers. Commercial poaching also seems to be well organised in the USSR and is a serious threat to wildlife, including the tiger. ${ }^{16}$

In 1976, after a 50-year period with no unprovoked tiger attacks on humans, a tractor driver was killed and partly eaten near the Lazo settlement, an isolated tragedy that may indicate an effect of increased disturbance and the destruction of prey species due to human settlement. It is hoped that nevertheless protection of these splendid animals will be continued. There are proposals to extend the Sikhote Alin and Lazov Reserves which are the tigers' main strongholds, and the large number in the world's zoos (at least 867 in 
1978) may serve as an insurance policy, but most encouraging is the commitment of the Soviet authorities to nature conservation. In 1978 there were 123 zapovedniki, or nature reserves, covering 9.5 million hectares, which are also centres for scientific research, and more than 1000 sanctuaries, and 50 million people were members of nature protection societies.

The Amur leopard also needs protection. Because it is so rare and elusive its changing status since the beginning of the century is not well documented, but its range has clearly become much more restricted than the tiger's. We know little about tiger and leopard status in north-east China, but numbers are probably very small in the forested mountains to the west of the Ussuri River, the Kentai Alin, Lao-e-lin and the Chang Pai Shan. In 1978 tigers were reported from the Wanta mountains further north, but it is not clear whether there are leopards there too. A few leopards and tigers may survive in the greater and lesser Khingan (Xingan) mountains in Heilongiiang province.

In the early years of this century Chinese settlers in the north-east feared leopards more than tigers, according to Baikov. ${ }^{17}$ The great cats were extensively hunted and pelts of Khingan leopards were especially prized. The great rivers which form the frontier between China and the USSR are no obstacle to the leopards, being frozen over for months at a time in winter. In any case leopards can swim well, though they do not take so readily to the water as do tigers. Some Soviet authorities believe that the increase in tigers near the border in some years may be due to animals crossing from China.

In Korea leopards were once common. They are now almost extinct in South Korea, and in the North, where they are protected in several reserves, notably in the Paekdu-san, numbers may not be much over 40 . In the 19 th century Korea sent both leopard and tiger pelts to the Chinese emperors as tribute. ${ }^{18}$

In the Soviet Far East today, leopards are found only in the extreme southern part of the Maritime Territory, mostly south of Lake Khanka in the Suchan, Sudzukhe and Suifun valleys, in the Cherny-Gori (Black Mountains) near the Chinese-North Korea frontier, and in the Lazov Preserve. They are rarely reported from as far north as the Sikhote Alin Reserve although they occasionally visit the Ussuri Reserve. ${ }^{19}$

The decline in Amur leopards in the last 60 years is mainly due to persecution by man for their fur and because of occasional stock predation, and live capture for zoos. Like tigers many have also been shot by hunters who regard them as competitors for the game. Hunted with dogs in winter, they have also been poisoned, trapped and snared. Both Prishvin in the early years of this century and Yankovsky in the 1920s record shooting leopards that raided their deer farms, ${ }^{20}$ but by the 1950 s only one or two were taken each year; present estimates of their numbers in the Soviet Far East are only about 40. Even allowing for the fact that leopards are extremely cautious and seldom seen even where they are numerous, there is no doubt that the Amur leopard is seriously endangered.

As early as 1916 reserves were set up in the Ussuri region. The Kedrovaya Pad (Cedar Ravines) Reserve near the Korean border gave the leopard some protection. The Suputinka (Ussuri) Reserve was created in 1932, and both are now being extended and incorporated into one huge reserve 200 miles long, so that the future of the Amur leopard seems more assured. Since 1956 killing leopards has been prohibited and prey species such as wild boars encouraged. Leopards that prey on domestic stock are captured and released into safe areas. 
However, a considerable number have been caught for zoos; between 1957 and 1972 no fewer than 30 were captured, mostly in the Suifun area. A short Soviet film Tiger Hunters, made in 1956, shows how leopards were pursued with dogs in winter, pinned down with forked sticks and tied up; young tigers were caught the same way.

This may seem difficult to accept when numbers in the wild are so low, and the number in zoos is still very small: only 20 males and 11 females are listed in the 1978 International Zoo Yearbook. Nevertheless captive breeding could still make an important contribution in their survival, and Frankfurt and Leipzig Zoos have had considerable breeding success. A pair bred at Frankfurt are exhibited at Howletts Zoo, near Canterbury. Their survival in the wild depends ultimately on whether their existence can be reconciled with the economic development of the Soviet Far East.

\section{Acknowledgment}

I should like to thank John Massey Stewart, Friedrike Guest and Arthur Goldwater for their valuable help with this article.

\section{References}

1. KUCHLER, A.W. 1948. A New Vegetation Map of Manchuria. Ecology 24.

2. THIEL, S. 1957. The Soviet Far East. Methuen, London.

3. ORIENTAL CERAMIC SOCIETY 1968. The Animal in Chinese Art. London.

4. STROGANOV, S.U. 1962. Carnivorous Mammals of Siberia. Moscow.

5. MAZAK, V. 1967. Notes on the Siberian long-haired tiger. Mammalia 31:4.

6. BARCLAY FORD, 1915. The Gun at Home and Abroad: The Big Game of Asia and North America. London.

7. ZHIRNOV, L.V. 1972. Tiger Protection in the USSR. Moscow.

8. OGNEV, S.I. 1935. Mammals of the USSR and Adjacent. Countries, Vol. 3. Moscow.

9. SOWERBY, A. de C. 1934. Game in the Maritime Province. The China Fournal, 21: 1 .

10. MATYUSHKIN, E.N., V.I. ZHYVOTCHENKO and E.N. SMIRNOV 1978. Tigers in the past, future and present in the USSR. In: Some Problems of Wildlife Conservation in the USSR. Moscow.

11. SYSOEV, V. 1960. Hunting in the Far Eastern Taiga. Khabarovsk.

12. MATYUSHKIN, E.N. 1978. Peculiarities of the distribution and ecology of the Amur tiger, as a geographical form of the species which has adapted to extreme conditions of the environment. In: International Tiger Studbook Congress Report of the First International Symposium on the Management and Breeding of the Tiger, 23-42. Leipzig.

13. BROMLEY, G.F., et al. 1978. Search and capture of prey of the Amur tiger.Ibid., 13-23.

14. PIKUNOV, D.G.et al. 1978. Ecological aspects of the life of the tiger in winter in the Maritime Territory. Ibid., 7-12.

15. WILlIAMSON, A. 1870. Journeys in North China, Manchuria and Eastern Mongolia with Some Account of Corea, Vol. 2. Smith, Elder, London.

16. YUDAKOV, A., and I.G. NIKOLAYEV 1973. Present state of Amur tiger population in the Primorye region.Zooligichesky Zhurnal 52:6.

17. BAIKOV, N. 1939. Les Bêtes Sauvages de la Mandchourie. Paris.

18. PERRY, R. 1964. The World of the Tiger. Cassell, London.

19. BROMLEY, G.F. 1977. The Plant and Animal World of the Ussuri Nature Preserve. Moscow.

20. PRISHVIN, M. 1936. Jen-Sheng, the Root of Life. New York. 